Arono, Emelda Syafrina, Features of English textbooks for the...

\title{
FEATURES OF ENGLISH TEXTBOOKS FOR THE FIRST- YEAR OF SENIOR HIGH SCHOOL IMPLEMENTING THE 2013-CURRICULUM
}

\author{
Arono \\ Emelda Syafrina \\ University of Bengkulu \\ E-mail: Emeldasyafrina372@yahoo.co.id
}

\begin{abstract}
This research aimed to investigate the quality of English for the First Year of Senior High School Implementing the 2013 Curriculum the academic years 2016/2017. The method applied in this research was descriptive method. Data collection techniques used observation check list. There were three textbooks observed. The aspects that were observed consisted of content, presentation, language, and graphic. The result indicated as follows. For the appropriateness the content of view; there were only two textbooks which belong to 'good' category books, namely Pathway to English for Senior High School Grade X, published by Erlangga and Bahasa Inggris SMA/MA/SMK/MAK Kelas $X$, published by Kemdikbud. An others textbook had 'fair' category namely Bahasa Inggris untuk SMA-MA/SMK kelas X, published by Yrama Widya. There was one textbook which was categorized into 'very good' presentation, namely Bahasa Inggris SMA/MA/SMK/MAK Kelas X, published by kemdikbud. while two other textbooks, namely Pathway to English for Senior High School Grade X and Bahasa inggris untuk SMAMA/SMK kelas $X$ had 'good' category. Concerning the language aspect, there was one textbook, nemely Bahasa Inggris SMA/MA/SMK/MAK Kelas X had 'very good' category. Two other textbooks, namely Pathway to English for Senior High School Grade X and Bahasa inggris untuk SMA-MA/SMK kelas $X$ had 'good' category. Concerning the graphic aspect, there were two textbooks which belonged to 'very good' category, namely Pathway for Senior High School Grade X and Bahasa Inggris SMA/MA/SMK/MAK Kelas $X$. An others textbook namely, Bahasa Inggris SMA- MA/ SMK kelas X had 'good' category. Thus, three textbooks had good category and be worthy to use because they fulfilled the quality of good textbook.
\end{abstract}

Key words: 2013-Curriculum, Textbook, Textbooks Quality

Abstrak: Penelitian ini bertujuan untuk mengetahui kualitas dari buku pelajaran bahasa Inggris Kelas sepuluh SMA yang menerapkan kurikulum 2013 tahun ajaran 2016/2017. Metode yang digunakan adalah metode deskriptif. Teknik pengumpulan data yaitu observasi yang menggunakan daftar cocok. Ada tiga buku teks yang diamati. Aspek yang diamati terdiri dari kelayakan isi, penyajian, bahasa, dan kegrafikan. Hasil kelayakan isi menunjukkan hanya ada dua buku yang masuk kategori buku bagus yaitu Pathway to English yang diterbitkan oleh Erlangga dan Bahasa Inggris diterbitkan oleh Kemdikbud. satu buku lain memiliki kategori cukup yaitu Bahasa Inggris yang diterbitkan oleh Yrama Widya. Hasi kelayakan presentasi ada satu buku dikategorikan ke dalam presentasi yang sangat baik yang yaitu Bahasa Inggris yang diterbitkan oleh Kemdikbud. Sementara dua buku lain yaitu Pathway to English yang diterbitkan oleh Erlangga dan Bahasa inggris yang diterbitkan oleh Yrama Widya memiliki kategori baik. Temuan dari aspek bahasa, ada satu buku yaitu Bahasa Inggris diterbitkan oleh Kemdikbud memiliki kategori sangat baik yang dua buku lain yaitu Pathway to English yang diterbitkan oleh Erlangga dan Bahasa yang diterbitkan oleh Yrama Widya memiliki kategori baik dan dari aspek grafis, ada dua buku yang termasuk kategori sangat baik yaitu Pathway to English yang diterbitkan oleh Erlangga dan Bahasa Inggris diterbitkan oleh Kemdikbud. satu buku lain yaitu Bahasa Inggris yang diterbitkan oleh Yrama Widya memiliki kategori baik. 
Dengan demikian, tiga buku teks memiliki kategori baik dan layak untuk digunakan karena memenuhi kualitas buku teks yang baik.

Kata Kunci : Kurikulum 2013, Buku teks, Kelayakan Buku

\section{INTRODUCTION}

Curriculum is a set of planning and organization of aim, content, and learning material as the guidance to learning activity to achieve a particular educational objective. Nowadays, Curriculum 2013 for senior high school in Indonesian had been implemented from grade $\mathrm{X}$ or first year of senior high school. Related to this explanation, there are several changes in some parts of education. According to Richards (2001) curriculum changes are of many different kinds likes content, methods and assessment in learning teaching process. Related to explanation above curriculum may affect teachers' pedagogical values and beliefs, teachers' understanding of the nature of language or second language learning, or their classroom practices and the use of teaching and learning materials. Among several changes in education parts teaching material also need to be adjusted because it is one of the most important factors in teaching and learning process. This argument is supported by Richards (2001). That argues that teaching materials are regarded as a key factor in most language programs.

Teaching materials can be developed from many learning sources, the material can be written or unwritten material likes student worksheet, visual, audio- visual, $\mathrm{CD}, \mathrm{VCD}$, and internet. One of them it is from textbook. Then it needs special attention regarding its changes toward recent applied curriculum. The adjustment of textbook to the recent curriculum should be conducted because English teachers tend to display a strong reliance on textbook usage.

A textbook means a created material designed as materials for teaching learning process in order to increase the learners' knowledge and experience. Cunningsworth (1995) stated that textbook is best seen as a source in achieving aims and objectives that have already been set in terms of learner needs. Textbook also can be defined as a book prepared for school's students in teaching learning process. It is used as a main component to deliver the material framework designed in the curriculum. They may deliver the foundation for the content of the lessons, the balance of skills taught and the types of language practice the students take part in.

In actually, textbook can varies based on the language teaching stakeholders. It can adapt the curriculum, the teacher needs, and also the students' needs. That is why, we can find a different textbook used in a different schools. Therefore, teachers have to choose the appropriate and ideal textbook as beneficial for both students and teacher as possible. However, on a particular occasion, learners' needs sometimes become the pin point for the teachers to determine a textbook. In other words, English teachers must be able to evaluate textbooks in order to find out if they were still worth using or need replacing.

According to Greene and Petty (1985) in Tarigan (2009) explain the criteria of good textbook. Such as: a textbook must be interesting and attractive toward the learners for instance the news information, newness material. Thus, they will be interested in using textbook, a textbook must be able to motivate the learners, a textbook should consider the linguistic aspect. In order that, it will be suitable with the learner's and a textbook must stimulate the personal activity of the learners. Correlated that in 2007 BSNP also launched instruments to evaluate English textbook in Indonesia they are: 
(1) Content feasibility (2) Language use feasibility (3) presentation feasibility and (4) Graphic feasibility. From the criteria above teachers were responsible for selecting good materials and needed to be able to make judgment about the textbook.

The selection of textbook used by teachers become relatively crucial because the textbook has to fit with the current curriculum, schools syllabus along with student's needs and also the aims and goals of teaching. Thus, researcher interested to analyzing English textbooks for the first year of senior high schools implementing 2013 curriculum by BSNP. Based on the explanation above the research questions was formulated as follow: How was the content aspect of English textbook for the first-year of senior high school cover the basic competencies of the 2013 curriculum?, How was the presentation aspect of English textbooks for the firstyear of senior high school?, How was the language use in English textbooks for the first-year of senior high school?, How was the graphic of English textbook for the first- year of senior high school?. The objective of this research is To describe the quality of English Textbooks for first year SMAN 4 in Bengkulu city, covering as follow: The coverage of basic competencies of the 2013- curriculum, the presentation, the language use and the graphic.

\section{METHODOLOGY}

The method used in this research is descriptive method. This is a research for non-statistical data analysis. This research focused how to analyze English textbook that implementing criteria of good textbook and curriculum 2013 requirement. According to Sugiyono (2012) descriptive method is a research that aims to understand the phenomenon of what is experienced by the subject of the study such behavior, perception, motivation, action and others. The subjects of this research were the English textbooks for the first year of senior high school based on the 2013 curriculum. The textbooks are "Pathway to English for Senior High School Grade $X$ " published by Erlangga, "Bahasa Inggris Untuk SMA-MA/ SMK kelas X" published by Yrama Widya and "Bahasa Inggris SMA/ MA/ SMK/ MAK kelas $X$ " published by Kamendikbud.

The instrument in this study was a checklist based on the textbook evaluation criteria based on BSNP (2016). There are four aspects of the textbooks to be evaluated in this research namely; content aspect, language aspect, presentation aspect and graphic aspect. The evaluation checklist used of a graduated scale 1- 4, researcher used by BSNP (2016) criteria with scale: 1 (very poor), 2 (poor), 3 (good) and 4 (very good).

The techniques of collecting data used in this research are documentation and observation checklist. The techniques of collecting the data in this research were done in several steps as follow (1) getting and distributing the document; (2) distributing the evaluation checklist to all evaluators; and (3) filling in the evaluation checklist done by evaluators by ticking the choice of scale 1-4 and filling in their opinions about the strengths and weaknesses of the material in the column provided. Data was conducted (May 2016 - September 2016). The time was selected with consideration of the usefulness of the results of this study.

In analyzing the data, the researcher took some steps they are: The researcher prepared English textbooks for the tenth grade student of senior high school. Then the researcher selected the chapters of each textbook to be analyzed, the researcher and two observers analyzed the relevance of four aspects analysis based on BSNP by using formula:

$$
\text { Where: }
$$$$
P=\frac{F}{N} \times 100 \%
$$

$\mathrm{P}=$ Descriptive Percentage

$\mathrm{F}=$ Frequency of each respondents answer

$\mathrm{N}=$ Total number of respondents 
Table 1. Interpretation of Cohen's kappa

\begin{tabular}{|c|c|c|}
\hline Value of Kappa & Level of Agreement & \% Data that are Reliable \\
\hline $0-20$ & None & $0-4 \%$ \\
\hline $21-39$ & Minimal & $3-15 \%$ \\
\hline $40-59$ & Weak & $35-63 \%$ \\
\hline $60-79$ & Moderate & $64-81 \%$ \\
\hline $80-90$ & Strong & $82-100 \%$ \\
\hline Above 90 & Almost Perfect & \\
\hline
\end{tabular}

Since the observation check list gave 4 of each category will be obtained by the alternatives (1 to 4 ) of answer, the interval formula:

$$
P=\frac{\mathrm{n}-1}{\mathrm{n}}
$$

Table 2. Mean Category of Textbook

\begin{tabular}{|c|l|}
\hline Score & \multicolumn{1}{|c|}{ Category } \\
\hline $3,41-4,00$ & Very Good \\
\hline $2,81-3,40$ & Good \\
\hline $2,21-2,80$ & Fair \\
\hline $1,61-2,20$ & Poor \\
\hline $1,00-1,60$ & Very Poor \\
\hline
\end{tabular}

After that, the researcher described and elaborated the findings of the analysis and the researcher determined the conclusion.

\section{FINDINGS AND DISCUSSION}

\section{Result Reliability Inter- Rater}

Analysis of English textbooks for High School Class $\mathrm{X}$ involves three assessors. They are two English teachers SMAN 4 Bengkulu as co- rater 1 and co- rater 2 and the researcher herself. This research was conducted by analyzing the English language textbooks based on content aspects, presentation, language use and graphic by BSNP. The score had correlated from inter- rater. The score was correlated when the score from the raters in the same category or interval. In this research reliability inter-rater illustrated in Table 3. 
Table 3. Summary Calculation of Percent Agreement between Raters

\begin{tabular}{|c|c|c|c|}
\hline $\begin{array}{c}\text { English } \\
\text { Textbooks }\end{array}$ & $\%$ Agreement & Level of Agreement & \% of Reliable \\
\hline Textbook 1 & $86.85 \%$ & Strong & Almost Perfect \\
\hline Textbook 2 & $85.93 \%$ & Strong & Almost Perfect \\
\hline Textbook 3 & $91.24 \%$ & Almost Perfect & Almost Perfect \\
\hline AVERAGE & $88.00 \%$ & Strong & Almost Perfect \\
\hline
\end{tabular}

Inter-rater correlation analysis result shown the average in textbook 1 was $(86.85 \%)$, indicating strong agreement and almost perfect reliable. The average in textbook 2 was $(85.93 \%)$, indicating strong agreement and almost perfect reliable. The average in textbook 3 was (91.24\%), indicating almost perfect agreement and almost perfect reliable. Total percent of agreement between three raters was $(88.00 \%)$, indicating the level of agreement of inter- raters is strong and reliable of inter- raters is almostperfect.

\section{The Result of Four Aspects of Textbooks}

Content Aspect

The result of analysis based on the contents aspect which consists of the material conformity with $\mathrm{KI}$ and $\mathrm{KD}$, accuracy of the materials, and supporting materials. It shown in Figure 1.

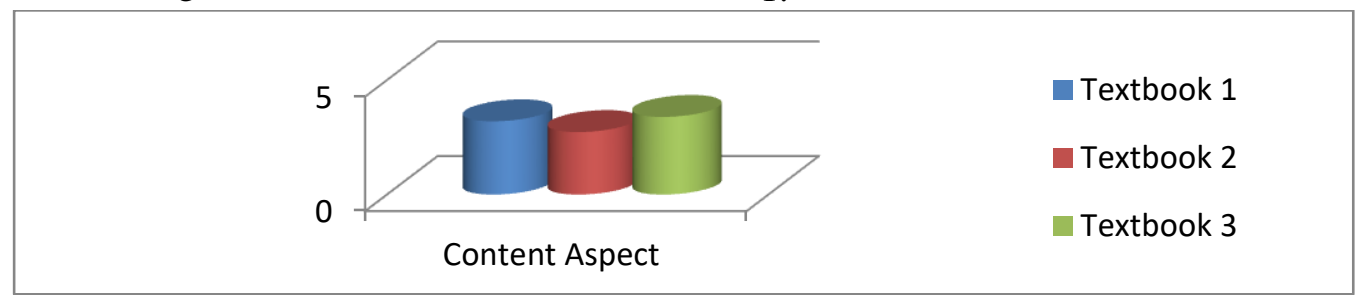

From figure1, it can be seen that the result was follows: The average in textbook 1 was (3.20), indicating good category, the average textbook 2 was (2.73), indicating fair category, and the average textbook 3 was (3.39), indicating good category. The textbook that got scale enough result, it should be corrected. There are three components based on the BSNP (National Education Standards assessed). The components are the relevance of materials to the curriculum, accuracy of the material, and learning support materials.

Presentation Aspect

The result of the presentation aspect illustrated in Figure 2.

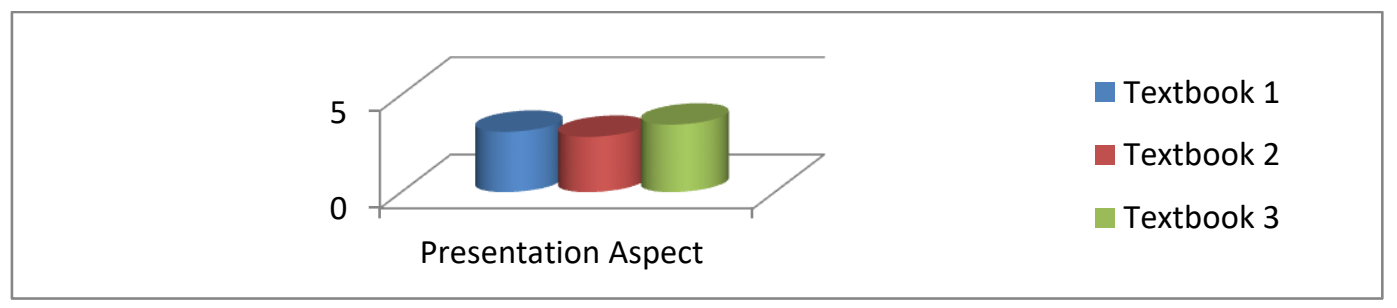

From figure 2, it can be seen that the results of the second instrument of presentation aspect of three textbooks were known the average of textbook 1 was (3.10), indicating good category. The average of textbook 2 was (2.84), indicating good category. The average textbook 3 was (3.47), indicating very good category. There are three component aspects in presentation such as presentation technique, teaching and 
learning technique, and presentation coverage.
The result of the language aspect presented in Figure 3.

a. Language Aspect

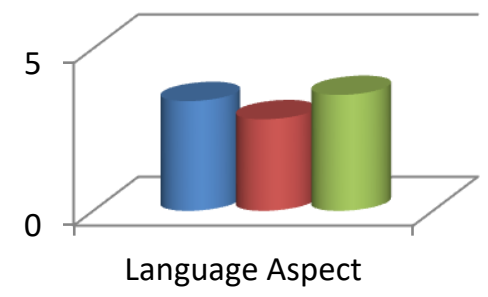

Textbook 1

- Textbook 2

Textbook 3

From figure 3, it can be seen that the result of the third instrument of appropriateness of language of three textbooks were known the average of textbook 1 was (3.38), indicating very good category. The average of textbook 2 was (2.82), indicating good category. The average of textbook 3 was (3.57), indicating very good category. Three textbook fulfilled the appropriateness of language such as the match between language and the students' development, communicative, the coherence and unity of ideas, four skill (listening, speaking, reading and writing) other language aspects (vocabulary, grammar and pronunciation). However, should be improvement for some aspect that still indicated low score.

\section{b. Graphic Aspect}

The result of the graphic aspect used instrument of BSNP. It shown in Figure 4.

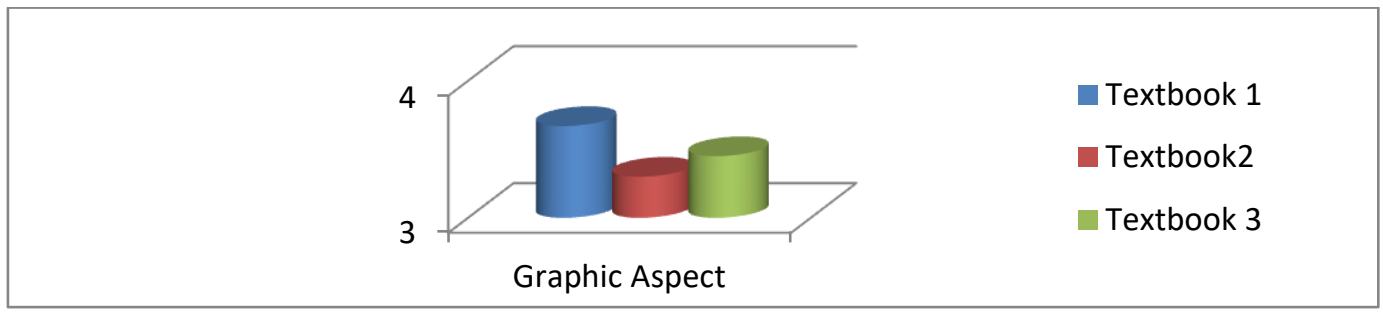

From Figure 4, it can be seen that the result of the forth instrument of graphic aspect of three textbooks were known the average of textbook 1 was (3.67), indicating very good category. The average textbook 2 was (3.30), indicating very good category. However, it still less in illustrated book content the score was (2.77), indicating fair category. It was because the letters used

\section{DISCUSSION}

The result of analysis of the contents aspect of three textbooks as follow: Two textbooks are good categorized that are Pathway to English by Erlangga and Bahasa Inggris by Kemdikbud because most of contents in textbooks were more than two kinds, used much of ornamental letters, illustrations reveal the contents of the object less proportional and less harmonious between the title, text, caption, illustration, in whole pages. The average textbook 3 was (3.45), indicating very good category. It concluded, three textbooks fulfilled the graphic aspect of BSNP.

relevant to SK and KD 2013Curriculum. The source material was varied and up to date, and deeper. It can also increase the knowledge, attitudes, and skills of students. However, one other textbook considered sufficient, the 
textbook is Bahasa Inggris by Yrama Widya. It was stated enough because most of the material presented less depth, less functional exercises, the material presented on the immediate environment did not familiar with the daily life of the participants (contextual). It conclude that the textbook did not display the contextual.

According to Richards (2001), textbooks are used in different ways in language programs. For example, a reading textbook might be the basis for a course on reading skills, providing both a set of reading texts and exercises for skills practice. A writing textbook might provide model compositions and a list of topics for students to write about. A grammar textbook might serve as a reference book and provide examples as well as exercises to develop grammatical knowledge. A speaking textbook might provide passages for students to read and discuss. A listening textbook together with audiocassettes or CDs might serve as the primary listening input in a listening course. That is way, we can find a different textbook used in a different schools as a basic guideline in teaching and learning process.

The finding of research by Prasojo (2014) also found the English textbook of Pathway to English for Senior High School Grade $X$ compatible with the curriculum 2013, as every single KI and KD successfully implemented in the textbook, and the materials provided in the textbook completely completed as all suggested English language skills exercises of writing, speaking, reading and listening materials in the curriculum 2013 were implemented. (Harimasyah, et al, 2008) stated that a textbook can be said to be good in content aspect, if noticed a complete reference that was accordance to the curriculum or syllabus, relevant science, and needs of learners.

Generally, Textbook 1 facilitated learners very well in improving learners' reading, writing, listening, and speaking skills through various functional texts and monologues. This can be seen in the integration of those four skills in enabling learners to comprehend and produce those functional texts both oral and written. Besides, given learners explicit guidance to acquire comprehension about the elements of functional texts production. That called social functions, generic structure, and linguistic features. Also the supporting materials in textbooks was contextual because generally adjusted so it can be used.

Moreover, this textbook lack of up to date material. It was because less equipped with a source of reference and the reference more than five year ago.As suggested by Ramadhan (2016) every item in supporting the materials and exercise provided within textbook (Tables, Pictures, Texts, references) should be taken from a relevance and newest sources available. It can be conclude that textbook 1 should be revised by supporting material such as text, table, picture, attachment, and others should be taken from the references that was relevant to the topic discussed and newest references about the topic discussed.

Textbook 2 was less required the learners to express quite many types of texts with various topics those were relevant to learners' daily life. In exploring narratives there were some stories only from local folktales. This textbook also was poor given the learners explicit guidance to acquire comprehension about the element of functional text production especially in guidance of generic structure. Text was given no explanation about structure of the text. As a result, the learners were difficult to understood, analyzed and produced a text.

In particular, supporting materials in this textbook was contextual because commonly adjusted so it can be used. Although less in up to date material it was because some texts did not taken from the up-to-date references and the textbook did not equipped with a source of reference. Those texts should be replaced with newest texts of the same 
type. Besides, this textbook less promoted of cultural diversity which covers local, national, and global contents of various cultural values.

It can be concluded that textbook 2 should be revised by doing some adoption. It was because the textbook did not provide depth of content which each texts were less completed by exposure, retention, formatting rules text, text production, and the extension through loading element (social function, elements and structures of meaning and linguistic features.

Textbook 3 relevance in SK (the core competence) and $\mathrm{KD}$ (the basic competence) which covered of four skills. Commonly, this textbook facilitated well in improving learners' listening, speaking, reading and writing skill through various text and monologue. This can be seen in the integration of those four skills in supporting learners to comprehend and produce functional texts both oral and written. This textbook also was given learners explicit guidance to acquire comprehension about the elements of social function, generic structure and linguistic features.

Besides, in supporting learning materials was contextual because almost category adjusted such as it was up to date material, developed life skill, developed insight and diversity, and character building. But this textbook still lacks on cultural aspect which the materials were less promoted cultural aspect that covered local, national and global content of various cultural values. It can be concluded that textbook 3 the materials should be revised and add more texts that containing the cultural aspects in order to improve aspects of student local, national and global culture.

The result of presentation aspect of three textbooks indicated good category. It was because textbooks content accordance with the level of ability of the students, the easily language understood, in this way, students want to read the textbook also required interesting presentation. According to Tarigan \& Tarigan (2009) a good textbook is a textbook that can make students desire, happy doing what instructions on textbooks, and adds student interest in learning also It has to do through presentation. Presentation was seen from the beginning of the book until the end of textbook. If the illustration of introduction was not interesting consequently, the students were unenthusiastic to read, and if the material presented was difficult so that the students were reluctant to read it.

Textbook 1 fulfilled a good textbook in presentation aspect. It was because the materials and tasks were systematization and balance among units. Besides, in teaching and learning technique was learners' centeredness, developed of learners' initiative, creativity, and critical thinking, developed of reflection and selfevaluation ability, genre based approach, and scientific approach. Then in opening has preface and table of content.

Nevertheless, this textbook still needs improvement because it lack of reference, summary and reflection. It was because a good textbook should contain reference, summary and reflections to facilitate learners' to understand the content of chapter, and conclusion of attitudes and behaviors that was succinctly and clearly. Also this textbook lack in closing. It was because this textbook does not provide glossarial pages, indexes, author information, and only references was provided.

Similliarly to Prasojo (2014) the textbook Pathway to English did not provide complete reference of the sources of their learning materials. Only a few parts cited their references. The conclusion part was also removed. It is perhaps removed due to the book itself that has already had self-reflection issues by the end of every chapter. However, a conclusion was still needed because it concluded that what the learning outcome, learning morale, and many others are. 
In order that, textbook Pathway to English by Erlangga should be revised. The textbook should add glossary for each text or unit. Thus, learners' unfamiliarity of difficult words can be facilitated explicitly. Besides, textbook can guide learners to make summary after each lesson. This will be helped for them concluded the material. Also the textbook should be completed about author information based on BSNP 2016. It was because allows people to know and communicate with the elements of book publishing, and can be delivered directly to the author or through the portal / page prepared, so that there is public involvement to control the quality of the book.

Textbook 2 indicated good category in presentation aspect. It was because some of criteria were fulfilled of a good textbook. In presentation technique the materials and tasks were systematization and balance among unit. In teaching and learning technique was developed of learners' initiative, creativity, and critical thinking, development of reflection and self-evaluation ability, genre based approach and scientific approach. Moreover, this textbook still needs revision in learner- centeredness. It was because each chapter did not contain of complete layout presentation that very encourages interaction in English among the student, between the student and the teacher and between student and wider environment and the activity cannot be used for self-study.

Also this textbook indicated good in opening which was realized preface and table of content and also good in closing that was textbook completed of glossary, bibliography and index. But lack in the content that as textbook less of introduction, learning load, reference, summary and reflection. It can be conclude that textbook 2 should be revised based on BSNP to be a good textbook that can be used for students.

Textbook 3 indicated very good category in presentation aspect. It was because all aspect criteria fulfilled based on BSNP. In presentation technique the materials and tasks were delivered systematization and balance among unit, the presentation of materials and tasks prompts interaction in English among the learners, between the learners and the teacher and learners' circumstances, and the activities can be used for selfstudy, on development of learners' initiative, and critical thinking.

The presentation of material and tasks prompts learners to do some communicative activities both oral and written also to be responsible towards their own learning process. On development of reflection and selfevaluation ability, the presentation of materials and tasks prompts learners to know their success and lack in doing learning activities and in communication. In genre based approach, the activities for building knowledge, modeling the text, joint construction of the text and independent construction of the text. In scientific approach the activities for knowledge and comprehension, application, analysis, evaluation and creation implemented 2013 curriculum.

In opening the textbook has preface and table of content. On content has introduction, the core of the textbook content, reference, summary and reflection. in closing has glossary, bibliography, indexes and information about author. It can be concluded that textbook 3 completed the presentation aspect. Because all aspects was fulfilled based on BSNP.

The subject and the right materials are only useful and can be understood when it was described with language who can understood by the students. The result of language aspect of three textbooks indicated good category and fulfilled the aspect in language aspect. It was because the language use on three textbooks match with student development, communicativeness, also the materials presented the coherence and unity ideas, focus of four skills (listening, speaking, reading and writing) and other language aspect such 
as vocabulary, grammar and pronunciation.

Languages were determined by the level of language skills of students and using standard language, the intent of the standard language effective sentence, to avoid a double meaning, modest, polite, and Interesting (Tarigan \& Tarigan, 2009 ). Mainly, the language used within each model text (interpersonal, transactional, and functional) was not significant mistakes in terms of grammar and vocabulary. Every single text used correct grammar and appropriate vocabulary according to the context. In conclusion, three textbooks was fulfilled the criteria of accurate and appropriate language based on BSNP.

For textbook 1, the language used in each explanation and instruction was relevant to learners' cognitive development. The explanation on grammar theories, vocabulary, social functions, generic structure, and linguistic features of certain text types was easily understood by learners. The summary on texts' purpose, text organization, and language features in the end of each unit also facilitated learners to comprehend the points of the lesson much faster and much more easily.

In this textbook the message presented in each unit was clear and easily understood by the learners. it was because the grammar and vocabulary explanation were brief and used familiar language. In addition, the topics chosen for each unit was learners' daily life and appealing for them. In turn, learners would find it easy to understand the message within the texts.

Besides, this textbook was lack of coherence and unity of ideas among units. It was because there was a sufficient similarity of topics between one unit and another, also lack of coverage of language content that was covering grammar, vocabulary, and pronunciation. It was because the texbook paid attention to grammar and vocabulary, but very little attention to pronunciation.

Similarly to Kinasih (2014) she also discussed Pathway to English. The language used within the instructions, explanations, or texts is very scientific and unfamiliar for the tenth graders and was not facilitated explicitly with glossary of unfamiliar words. Thus, it was not relevant to learners' cognitive development. The language also was not relevant to learners' socio-emotional development, because most of the topics are scientific and therefore too demanding for learners. Pathway to English was lacking in terms of language content, because there was not enough explanation and practice for vocabulary comprehension. The lack of vocabulary lessons was a huge problem considering that this texbook has a lot of scientific and unfamiliar words. On the other hand, the texts contained many scientific words which were hard for learners to comprehend.

It can be conclude that textbook 1, the vocabulary lessons and explanation of pronunciation should be improved to make learners more familiar to the scientific terminologies in the textbook

In Textbook 2, the language used in each explanation and instruction was relevant to learners' cognitive development. The explanation on grammar theories, vocabulary, social functions, generic structure, and linguistic features of certain text types was easily understood by learners. The summary on texts' purpose, text organization, and language features in the end of each unit also facilitated learners to comprehend the points of the lesson faster and more easily.

In this textbook, the message presented in each unit was clear and easily understood by learners. This was because the grammar and vocabulary explanation were brief and used familiar language. In addition, the topics chosen for each unit are of learners' daily life and are appealing for them. In turn, learners would find it easy to understand the message within the texts. 
Moreover, In the textbook there was lack of coherence and unity of ideas among units. This was because there was sufficient similarities of topics between one unit and another also deficiency of coverage of language content that was covering grammar, vocabulary, and pronunciation. This was because the book paid attention to grammar and vocabulary, but very little attention to pronunciation.

In Textbook 3, the language used in each explanation and instruction was relevant to learners' cognitive development. The explanation on grammar theories, vocabulary, social functions, generic structure, and linguistic features of certain text types was easily understood by learners. The summary on texts' purpose, text organization, and language features in the end of each unit also facilitated learners to comprehend the points of the lesson much faster and much more easily.

In this textbook, the message presented in each unit was clear and easily understood by learners. This was because the grammar and vocabulary explanation were brief and used familiar language. In addition, the topics chosen for each unit are of learners' daily life and are appealing for them. In turn,

\section{CONCLUSION}

Based on the results of research and discussion, it can be concluded that: In terms of contents aspect based on the textbook evaluation devised BNSP, that textbooks 1 and textbook 3 belong to good textbooks. However, it should be revised by supplementing textbooks with up to date materials and cultural aspects. Textbook 2 still falls onto fair category. This book requires heavier revision in material depth, generic structure, up to date materials and cultural aspects. In order that fulfill the criteria of a good textbook, especially in content aspect.

In terms of the presentation aspect based on the textbook evaluation learners would find it easy to understand the message within the texts. The materials presented on coherence, show unity and sequenced from easy to complex.

Then the result of three textbooks indicated good category in graphic aspect. It was verified textbook 1 indicated very good category, textbook 2 and textbook 3 indicated good category. (Muslics,2010) stated that graphic note in the textbook are : a) The size of the book; b) Design leather book / appearance of the cover (appeal, typography, and illustration); c) Design of contents book; d) illustration (type, attractiveness, anatomy); e) the suitability of the paper;

The textbook must be interesting and attractive toward the learners. Thus, they will be interested in using textbook (Greene and Petty: 1971). Based on explanation above a good textbook was the content matter, need to be more physical. Appearance supports the content, without the appearance of good students will not be interested to read it, and without good content, students will not be understood what is contained in the book. It can interesting to have students in terms of physical, cover, illustration, and appearance of each chapter, as well as the color, fonts.

devised BNSP, textbook 3 got a very good category. Textbook 1 and textbook 2 belongs to good category. However, need improvement in learning centeredness, genre - based approach and presentation coverage on content and closing. In order that, these textbooks fulfill the criteria of a good book, especially in presentation aspect.

In terms of language aspect textbook evaluation devised by BNSP, textbook 3 shown that very good category. Textbook 1 and textbook 2 belongs to good category. Besides, need revision in the coherence and unity of ideas and presentation and practice in other language aspect such as vocabulary, 
grammar and pronunciation. In order that, these textbooks fulfill the criteria of a good book, especially in language aspect.

In terms graphic aspect based textbook evaluation devised by BNSP shown textbooks 1 and textbook 3 had very good category. Besides, textbook 2 had good category.

\section{REFERENCES}

Agus, A. (2016). An analysis on English textbook pathway to English for the first year student of senior high school based on 2013 curriculum. UMS: Published Thesis

Arikunto, S. (2010). Prosedur penelitian suatu pendekatan praktik. Jakarta: Rineka Cipta.

Ayaturrochim. (2014). "The analysis of reading tasks in "English in focus" textbook based on cognitive domain of revised bloom's taxonomy." Thesis, English Language Education Study Program, Education and Teachers Training Faculty, Bengkulu University

Badan Standar Nasional Pendidikan, (2014). Standar isi untuk acuan pendidikan dasar dan menengah. Jakarta: BSNP

Badan Standar Nasional Pendidikan, (2016). Standar isi untuk acuan pendidikan dasar dan menengah. Jakarta: BSNP

Chandran, S. "Where are the ELT Textbook?". in Willy A. Renandya (Ed.), Methodology and Materials Design in Language Teaching:Current Perception and Practices and their Implications. Singapore : SEAMEO Regional language centre. 2003.

Cunningsworth, A. (1995). Choosing your course book. New York: Macmillan.

Farisi, M. I. (2012). Buku teks sebagai psychological tool prosess enkulturasi dan pelestarian kearifan lokal. Prosiding Temu
Ilmiah Nasional Guru IV. Tangerang: Universitas Terbuka.

Hutchinson, T. \& Torres, E. (2004). The textbook as agent of change. ELT Journal, 48 (4), 315-328.

Kementrian Pendidikan dan Kebudayaan.(2016) Revisi bahasa Inggris/ kementrian pendidikan dan kebudayaan. - Jakarta: Kementrian Pendidikan dan Kebudayaan indonesia.

Kementrian Pendidikan dan Kebudayaan Dokumen Kurikulum 2013. (2012). http://www.kemendikbud.edu

Kinasih, A. K. (2014). A content analysis on English textbooks for the tenth graders: Look Ahead an English course for senior high school students' year $X$ and Pathway to English for senior high school student grade X. UNJ: Published Thesis

Mchugh, M. (2012). Interrater reliability: the Kappa Statistic biochemia medira. http://dx.doi.org/10.11613/BM20 12.031

Muslich, M. (2010).Text book writing: Dasar- dasar pemahaman, penulisan dan pemakaian buku teks.Yogyakarta: Ar- Ruzz Media

Muzakir. (2012). Penulisan buku teks yang berkualitas(Artikel Jurnal Online).

http://www.google.com/file.upi.

Nation, I. S. P. \& Macalister. J. (2010). Language curriculum design. New York \& London: Routledge.

Peraturan Menteri Pendidikan dan Kebudayaan Republik Indonesia Nomor 8 Tahun 2016. Buku teks pelajaran. Menteri Pendidikan dan Kebudayaan Republik Indonesia. Jakarta

Peraturan Menteri Pendidikan dan Kebudayaan Republik Indonesia Nomor 24 Tahun 2016.Kompetensi inti dan kompetensi dasar lampiran 47. Menteri Pendidikan dan Kebudayaan Republik Indonesia. Jakarta. 
Prasojo, A. (2014). The analysis of English textbook "Pathway to English" used in the first grade of senior high school based on curriculum 2013. UIN: Published Thesis.

Ramadhan, F. A. (2016). A content analysis based on contextual learning materials in curriculum 2013 textbook 'talk active'. UIN: published thesis.

Richard, Jack, (2001). Curriculum development in language teaching. USA Cambridge university press

Setiawan, D. O. (2013) Bahasa Inggris / oleh Otong Setiawan Dj..- Cet.1. Bandung: Yrama Widya.

Subariyah. (2014). An analysis on the suitability of the English textbook pathway to English for the tenth grade students of senior high school based on Tomlinson's theory. UMS: published Thesis

Sudarwati, TH. M. \& Grace, E. (2013). Pathway to English for Senior High School and MA Grade X. Jakarta: Erlangga.

Sugiyono. (2010). Metode penelitian pendidikan. Cetakan kedua belas, Bandung : Alfabeta.

Sukmadinata,N.S.(2010).

Pengembangan Kurikulum Teori dan Praktek. Bandung: PT remaja rosdakarya offset.

Tarigan, H. G. (2009). Dasar- dasar kurikulum bahasa. Bandung:Penerbit Angkasa

Tarigan, H.G. \& Tarigan, D. (2009). Telaah Buku teks bahasa Indonesia. Bandung : Penerbit Angkasa

Tanner, D. \& Tanner, L. N. (1980). Curriculum development. New york: Macmillan.

Tomlinson, B. (2003). Materials Evaluation. In Tomlinson, B. (ed). Developing Materials for Language Teaching. London and New York: Continuum.

Ur, Penny. (2009). A course in language teaching practice and theory.
New York: Cambridge University

Press

W.,Ganjar Harimansyah, dkk. (2008).

Pengembangan model

pembelajaran: uji efektivitas bahan ajar BIPA. Jakarta:Pusat Bahasa Departemen Pendidikan Nasional. 